\title{
Update on the Management of Aspirin-Exacerbated Respiratory Disease
}

\section{Citation}

Buchheit, Kathleen M., and Tanya M. Laidlaw. 2016. "Update on the Management of AspirinExacerbated Respiratory Disease." Allergy, Asthma \& Immunology Research 8 (4): 298-304. doi:10.4168/aair.2016.8.4.298. http://dx.doi.org/10.4168/aair.2016.8.4.298.

\section{Published Version}

doi:10.4168/aair.2016.8.4.298

\section{Permanent link}

http://nrs.harvard.edu/urn-3:HUL.InstRepos:27822132

\section{Terms of Use}

This article was downloaded from Harvard University's DASH repository, and is made available under the terms and conditions applicable to Other Posted Material, as set forth at http:// nrs.harvard.edu/urn-3:HUL.InstRepos:dash.current.terms-of-use\#LAA

\section{Share Your Story}

The Harvard community has made this article openly available.

Please share how this access benefits you. Submit a story.

\section{Accessibility}




\title{
Update on the Management of Aspirin-Exacerbated Respiratory Disease
}

\author{
Kathleen M. Buchheit, ${ }^{1,2 *}$ Tanya M. Laidlaw ${ }^{1,2}$ \\ 'Department of Medicine, Harvard Medical School, Boston, MA, USA \\ ${ }^{2}$ Division of Rheumatology, Immunology, and Allergy, Brigham and Women's Hospital, Boston, MA, USA
}

This is an Open Access article distributed under the terms of the Creative Commons Attribution Non-Commercial License (http://creativecommons.org/licenses/by-nc/3.0/) which permits unrestricted non-commercial use, distribution, and reproduction in any medium, provided the original work is properly cited.

Aspirin-exacerbated respiratory disease (AERD) is an adult-onset upper and lower airway disease consisting of eosinophilic nasal polyps, asthma, and respiratory reactions to cyclooxygenase 1 (COX-1) inhibitors. Management includes guideline-based treatment of asthma and sinus disease, avoidance of COX-1 inhibitors, and for some patients aspirin desensitization followed by high-dose aspirin therapy. Despite this, many patients have inadequately controlled symptoms and require multiple sinus surgeries. In this review, we discuss the current standard approaches to the management of AERD, and we introduce several therapeutics under development that may hold promise for the treatment of AERD.

Key Words: Aspirin-exacerbated respiratory disease; Samter's triad; nasal polyps; aspirin desensitization

\section{INTRODUCTION}

Aspirin-exacerbated respiratory disease (AERD) is an acquired inflammatory disease of the upper and lower airways and is characterized by eosinophilic sinusitis with recurrent nasal polyps, asthma, and respiratory reactions to medications that inhibit cyclooxygenase 1 (COX-1). It occurs in $7 \%$ of all adult asthmatics, but is found in a disproportionately higher number of adults with severe asthma. ${ }^{1}$ Onset of symptoms typically occurs in young adulthood with nasal congestion, sinus disease, and nasal polyposis, followed by development of asthma symptoms, then hypersensitivity to COX-1 inhibitors² ${ }^{2}$ however, symptoms do not necessarily arise in that sequence and not all patients have prominent lower respiratory symptoms. Upon ingestion of a COX-1 inhibitor, such as aspirin or a nonsteroidal anti-inflammatory drug (NSAID), patients develop upper and/or lower airway symptoms within 30-120 minutes, which often include rhinorrhea, nasal congestion, ocular pruritus and erythema, and bronchospasm. ${ }^{3}$ Some patients also develop skin symptoms such as rash and flushing, or gastrointestinal symptoms such as abdominal pain, vomiting, or diarrhea ${ }^{4}$ However, systemic symptoms involving the cardiovascular system are rare. Exposure to a COX-1 inhibitor is not in itself the cause of the disease, but instead exacerbates the underlying pathobiology, resulting in an acute hypersensitivity reaction that leads to the more severe clinical manifestations. Symptoms are chronic and often progressive in nature regardless of exposure to aspirin or NSAIDs. Diagnosis is suspected when clinical history is compatible with AERD, but aspirin challenges are required to confirm diagnosis when the patient has no history of NSAID exposure or if clinical history is uncertain. ${ }^{5}$ Currently, there are no available biomarkers with sufficient sensitivity and specificity to independently confirm a diagnosis of AERD. ${ }^{6}$

Mechanisms underlying AERD are not completely understood, but are known to involve abnormal arachidonic acid metabolism with overproduction of cysteinyl leukotrienes $(\mathrm{CysLTs})^{7,8}$ and proinflammatory prostaglandins (PGs) ${ }^{9,10}$ as well as underproduction of the anti-inflammatory prostaglandin PGE $2 .{ }^{11}$ At the tissue level, the disease is characterized by eosinophilic inflammation of the sinus and bronchial mucosa ${ }^{12}$ with the presence of degranulated mast cells ${ }^{13}$ and an increase in platelet-adherent leukocytes. ${ }^{14}$ The pathogenesis of aspirininduced reactions may reflect depletion of COX-1-dependent production of $\mathrm{PGE}_{2}$ leading to further tissue inflammation and an acute increase in upper and lower airway symptoms. ${ }^{15}$ Here, we will review the management of AERD and will discuss novel therapeutics that may target the underlying pathobiology of the disease.

Correspondence to: Kathleen M. Buchheit, MD, Brigham and Women's Hospital, One Jimmy Fund Way, Smith Building, Room 638, Boston, MA 02115, USA.

Tel: +617-525-1300; Fax: +617-525-1310; E-mail: kbuchheit@partners.org Received: June 24, 2015; Accepted: July 24, 2015

- There are no financial or other issues that might lead to conflict of interest. 


\section{MANAGEMENT}

Standard management of AERD involves treatment of asthma and chronic rhinosinusitis (CRS) as per published guidelines $^{16,17}$ with the addition of leukotriene-modifying medications for all patients and aspirin/NSAID avoidance. In most cases, aspirin desensitization and initiation of high-dose daily aspirin is also beneficial.

\section{Aspirin desensitization}

Aspirin desensitization is a safe and effective tool for the management of AERD when performed by experienced physicians. Indications for aspirin desensitization in AERD include failure of standard medical therapies, need for frequent oral corticosteroid bursts, and recurrent nasal polyps. ${ }^{18}$ Aspirin desensitization can also be performed when patients with AERD require daily aspirin therapy for an alternate reason, such as coronary artery disease. ${ }^{19,20}$ Desensitization may be required for patients with chronic pain requiring NSAIDs. Alternative agents, such as acetaminophen or celecoxib are generally safe, but in high doses may elicit reactions in some very sensitive AERD patients. ${ }^{21}$

Stevenson $e t$ al. $^{22}$ conducted the first randomized, placebocontrolled trial of aspirin desensitization for AERD in 1984. Following aspirin desensitization, most patients on high-dose aspirin experienced improvement in sinonasal symptoms and half of the patients experienced improvement in their asthma symptoms as well. ${ }^{22}$ Subsequent observational studies confirmed that aspirin desensitization followed by high-dose aspirin therapy improves upper and lower respiratory symptoms, slows polyp regrowth, and decreases topical and oral corticosteroid use. ${ }^{23-26}$ The results of a second double-blind, placebocontrolled study of aspirin desensitization and high-dose aspirin treatment in AERD were recently published. As compared to a control group of AERD patients who were treated with a placebo, the patients with AERD who were desensitized to aspirin and treated with $624 \mathrm{mg}$ of daily aspirin for 6 months demonstrated improvement in sinonasal and asthma symptoms with reduction in inhaled corticosteroid use. ${ }^{27}$

Benefits of high-dose daily aspirin therapy include slowed nasal polyp regrowth and reduced need for sinus surgery, ${ }^{23,28} \mathrm{im}$ proved sense of smell, decreased need for topical and oral corticosteroids, and reduced frequency of sinus infections. ${ }^{24}$ Targeting patients who have required multiple endoscopic sinus surgeries for polyp removal provides significant benefits. A retrospective analysis found that over a 2-year period, no patients who were on daily aspirin required repeat polypectomies, whereas $80 \%$ of the patients not on aspirin required repeat polypectomies. ${ }^{23}$ Another study with long-term follow-up after aspirin desensitization demonstrated longer surgery-free intervals, with patients on daily aspirin requiring surgery only every 10 years (instead of every 3 years off aspirin). ${ }^{26}$ An economic analysis found aspirin desensitization and continued high-dose aspirin therapy to be cost-effective in reducing the need for subsequent medical interventions, even after accounting for the up-front cost of aspirin desensitization. Aspirin desensitization in AERD patients requiring aspirin for coronary artery disease is also more cost-effective than prescribing alternative antiplatelet agents. ${ }^{29}$

The optimal dosage of aspirin following desensitization was investigated in a study of patients taking either aspirin $325 \mathrm{mg}$ twice daily or $650 \mathrm{mg}$ twice daily. While both doses were efficacious and occurrence of side effects was similar in both groups, some patients randomized to aspirin $325 \mathrm{mg}$ twice daily had to increase the dose to aspirin $650 \mathrm{mg}$ twice daily to adequately control symptoms..$^{30}$ Thus, high-dose aspirin therapy may need titration for adequate control of symptoms. A dose of aspirin $650 \mathrm{mg}$ twice daily is a reasonable starting dose, which may be continued for an initial period of 2 months and then decreased to the lower dose of $325 \mathrm{mg}$ twice daily to determine if the patient can maintain satisfactory symptom control.

A recent study described a subset of AERD patients who had difficulty tolerating aspirin desensitization due to severe extrarespiratory symptoms, including cutaneous and/or gastrointestinal symptoms. These subjects were found to have strikingly dysregulated production of prostaglandins, with dramatically increased production of $\mathrm{PGD}_{2}$ during their aspirin-induced reactions. ${ }^{4}$ In the authors' experience, pretreatment with oral cromolyn, a mast cell stabilizer, and zileuton, a 5-lipoxygenase inhibitor, before attempting aspirin desensitization can help these patients tolerate the desensitization procedure to allow for initiation of high-dose aspirin therapy. Decreasing the rate of dose escalation during the aspirin desensitization procedure can also be helpful in allowing these patients to tolerate the desensitization.

Although nearly all patients with AERD can be desensitized to aspirin, there is a subgroup of patients who do not symptomatically improve following aspirin desensitization. In a long-term retrospective analysis of 172 patients after aspirin desensitization, $22 \%$ of the subjects reported no improvement in symptoms, or they discontinued aspirin due to side effects. ${ }^{24}$ Additionally, contraindications to aspirin, including pregnancy and a history of gastric ulcers, prevent some patients from initiating daily aspirin. Therefore, while high-dose aspirin therapy can provide excellent results, continued pursuit of more efficacious, better-tolerated targeted therapies will benefit many patients with AERD.

\section{Leukotriene-modifying agents}

Given the overproduction of CysLTs in AERD, targeting the leukotriene pathway with either leukotriene receptor antagonists such as montelukast or 5-lipooxygenase inhibitors such as zileuton is intuitive. Several studies have evaluated the effect of montelukast on lower airway symptoms in AERD. In a doubleblind placebo-controlled study of aspirin-intolerant asthmatics 
on moderate-to-high dose glucocorticoids, montelukast was shown to improve lung function, reduce bronchodilator use, reduce asthma exacerbations, and improve quality of life. ${ }^{31}$

Leukotriene-receptor antagonists also modify upper airway symptoms in AERD, as montelukast has been shown to decrease nasal symptoms during lysine aspirin challenge. ${ }^{32}$ In a prospective study of the effect of montelukast on nasal polyposis, 3 months of montelukast therapy improved subjects' nasal symptom scores and decreased the nasal polyp tissue eosinophilia. The improvement was most significant in patients with perennial allergies. ${ }^{33}$ However, this study was limited in that no placebo was used and it did not specifically target patients with AERD.

In a recent cross-sectional survey questionnaire evaluating perceived effectiveness of therapeutic interventions by 190 AERD patients, $88 \%$ of respondents had been treated with leukotriene-receptor antagonists, whereas only $24 \%$ of respondents had been treated with a 5-lipoxygenase inhibitor. Although leukotriene-receptor antagonists were more widely prescribed for AERD, only $15 \%$ of subjects found them extremely effective, whereas $28 \%$ of subjects found zileuton to be extremely effective. ${ }^{34}$ While patients report more benefit from zileuton than from leukotriene-receptor antagonists, it is less frequently prescribed in AERD. This may be in part due to concern for liver toxicity and recommended transaminase monitoring while on zileuton. Analysis of liver testing results in patients on zileuton found that ALT elevations greater than 3 times the upper limit of normal occurred in $4.2 \%$ of patients on zileuton vs $1.1 \%$ of patients on placebo. Most of the elevations occurred in the first 3 months of therapy, and only $16 \%$ of those patients were symptomatic. ${ }^{35}$ In another prospective trial of controlled release zileuton for patients with asthma, ALT elevations were 3 times the upper limit of normal in $1.8 \%$ of patients taking zileuton and in $0.7 \%$ of patients on placebo, and all laboratory abnormalities resolved after stopping zileuton. ${ }^{36}$ When clinically indicated, zileuton can be safely used with appropriate monitoring of transaminases and may provide additional benefit to patients with AERD. Simultaneous use of a leukotriene-receptor antagonist and a 5-lipoxygenase inhibitor in AERD has not been studied, but may provide benefit in patients who are not adequately controlled on either agent independently.

\section{Omalizumab}

There are several case reports suggesting that omalizumab may help to improve AERD symptoms and decrease the symptoms of aspirin challenges. ${ }^{37,38}$ In a proof of concept, doubleblind, placebo-controlled study of allergic and nonallergic patients with nasal polyps and asthma, there was a significant decrease in the total nasal endoscopic score in the treatment group. Twelve of the 24 patients in the study had aspirin sensitivity by history. ${ }^{39}$ In the recent survey questionnaire of 190 AERD patients, only 16 patients had ever been treated with omalizumab. Of those patients, $57 \%$ found it to be somewhat or extremely effective in treating symptoms. ${ }^{34}$ The mechanism by which omalizumab is effective is unclear since neither the chronic inflammatory symptoms of AERD nor the aspirin-induced reactions are IgE-mediated. Despite this, many patients with AERD have been found to have elevated baseline IgE levels. ${ }^{40}$ The use of omalizumab in AERD requires further studies of both mechanism and efficacy.

\section{Immunotherapy}

Environmental allergen immunotherapy is not recommended as the standard of care for AERD, nor has it been formally investigated as a treatment specifically for AERD. The high prevalence rates of sensitization to environmental aeroallergens in the general population are paralleled in AERD, and thus many patients with AERD have comorbid allergic rhinitis. In the previously discussed survey questionnaire, $45 \%$ of subjects had concomitant allergic rhinitis and were on allergen immunotherapy. Of subjects on immunotherapy, $62 \%$ did not find it effective ${ }^{34}$ which is a much higher treatment failure rate than is commonly expected in patients with allergic rhinitis. Given the severe sinus inflammation and nasal polyposis in AERD, the effect of immunotherapy may not be sufficient to yield improvement in sinonasal symptoms. Therefore, it may be best to prescribe allergen immunotherapy only to those AERD patients who experience clear seasonal or perennial allergic symptoms in addition to their symptoms attributable to chronic nasal polyposis.

\section{Investigational therapies}

There are several ongoing studies of novel drugs in AERD (Table), along with many new agents that may show promise in AERD and eosinophilic nasal polyposis. Current clinical trials for AERD in the United States are investigating platelet-targeted therapies, including a $\mathrm{P}_{2} \mathrm{Y}_{12}$-receptor antagonist (NCT01597375) and a thromboxane-receptor (TP) antagonist (NCT02216357).

$\mathrm{P}_{2} \mathrm{Y}_{12}$ is a $\mathrm{G}$ protein-coupled receptor important in platelet activation and aggregation. Thienopyridines, such as clopidogrel and prasugrel, are a class of selective $\mathrm{P}_{2} \mathrm{Y}_{12}$ inhibitors used in acute coronary syndromes for their antiplatelet activity. They are known to decrease the development of platelet-leukocyte aggregates. ${ }^{41}$ At the tissue level, there is evidence that plateletadherent leukocytes contribute to inflammation in AERD. ${ }^{14}$ Several studies in mice suggest that platelets respond to CysLTs, leading to pulmonary inflammation, which can be blunted by $\mathrm{P}_{2} \mathrm{Y}_{12}$ antagonism. ${ }^{42,43}$ The $\mathrm{P}_{2} \mathrm{Y}_{12}$ inhibitor prasugrel is currently under investigation in a double-blind, placebo-controlled crossover study to determine if $\mathrm{P}_{2} \mathrm{Y}_{12}$ blockade reduces the severity of aspirin reactions during aspirin challenge.

TP-receptor signaling is known to induce bronchoconstriction. In a murine model of AERD, both TP-receptor antagonism and genetic deletion of TP receptors prevented reaction to ly- 
Table. Medications for the treatment of asthma, AERD, and/or nasal polyps

\begin{tabular}{|c|c|c|c|c|}
\hline Drug & Mechanism of action & Development & Comments & Ref \\
\hline Montelukast Zafirlukast & CysLTR1 antagonists & $\begin{array}{l}\text { Both are FDA and EMA approved } \\
\text { for treatment of asthma }\end{array}$ & $\begin{array}{l}\text { Studies show improvement in upper } \\
\text { and lower airway symptoms }\end{array}$ & 31,32 \\
\hline Zileuton & 5-lipoxygenase inhibitor & FDA approved for treatment of asthma & $\begin{array}{l}\text { Requires monitoring of transaminases, } \\
\text { all cases of hepatotoxicity resolved } \\
\text { after discontinuation of medication }\end{array}$ & $34-37$ \\
\hline Omalizumab & Binds free $\lg E$ & FDA and EMA approved & $\begin{array}{l}\text { A study in patients with nasal } \\
\text { polyps showed decrease in the total } \\
\text { nasal endoscopic score }\end{array}$ & $37-39$ \\
\hline Prasugrel & $\mathrm{P} 2 \mathrm{Y}_{12}$ receptor antagonist & $\begin{array}{l}\text { FDA approved for acute coronary } \\
\text { syndrome; Phase II for AERD }\end{array}$ & $\begin{array}{l}\text { Under investigation in AERD to determine } \\
\text { if it attenuates severity of aspirin reactions }\end{array}$ & NCT01597375 \\
\hline Ifetroban & TP receptor antagonist & Phase II & $\begin{array}{l}\text { Under investigation in AERD to determine } \\
\text { if it attenuates severity of aspirin reactions }\end{array}$ & NCT02216357 \\
\hline $\begin{array}{l}\text { ARRY-502 } \\
\text { AZD1981 } \\
\text { OAW039 } \\
\text { OC000459 }\end{array}$ & CRTH2 antagonists & Phase II & Not yet studied in AERD & \\
\hline Mepolizumab & Blocks IL-5 & Phase II/II & $\begin{array}{l}\text { Has been studied in asthma, recently } \\
\text { completed study in nasal polyps }\end{array}$ & 52, NCT01362244 \\
\hline Dupilumab & Blocks IL-4R $\alpha$ & Phase II & $\begin{array}{l}\text { Has been studied in asthma, recently } \\
\text { completed study in nasal polyps }\end{array}$ & NCT01920893 \\
\hline
\end{tabular}

sine aspirin challenge, ${ }^{44}$ suggesting that TP antagonism may provide therapeutic benefit in humans. Furthermore, a polymorphism of the thromboxane A2 receptor (TBXA2R) was associated with AERD in a Korean population. ${ }^{45}$ Ifetroban, an oral TP-receptor antagonist, is undergoing a double-blind, randomized, placebo-controlled safety and efficacy study in patients with AERD. The primary outcome under investigation is the severity of aspirin reactions in subjects.

Several drugs in development for other immune diseases may also prove to be efficacious in AERD. Targeting the effects of $\mathrm{PGD}_{2}$, which is an inflammatory lipid known to be overproduced in AERD, ${ }^{10}$ may provide therapeutic benefit. $\mathrm{PGD}_{2}$ and its stable metabolites signal through the $G$ protein-coupled receptor chemoattractant receptor-homologous molecule expressed on Th2 lymphocytes (CRTH2) to activate and recruit eosinophils, basophils, Th2 lymphocytes, and type 2 innate lymphoid cells. A recent study showed that a urinary metabolite of $\mathrm{PGD}_{2}$ was elevated at baseline in AERD patients with the most severe respiratory reactions to aspirin and further increased during their aspirin-induced reactions. $\mathrm{PGD}_{2}$, likely released by activated mast cells in the respiratory tissues, may have a role in the recruitment of $\mathrm{CRTH} 2^{+}$-effector cells like eosinophils and basophils to respiratory tissues in AERD. ${ }^{4}$ Several orally bioavailable CRTH2 antagonists are currently in development for asthma and allergic diseases, and may be well-suited to specifically decrease inflammation in respiratory tissues of patients with AERD.

Two cytokine-targeting drugs, mepolizumab and dupilumab, in development for asthma, may also be of use in nasal polyposis and AERD. Mepolizumab, a humanized monoclonal antibody, which binds to free IL-5 preventing it from associating with the IL-5 receptor on eosinophils, has shown promise treating patients with eosinophilic asthma. ${ }^{46-51}$ IL- 5 is known to be an important factor in the survival and differentiation of eosinophils, which are the dominant cell type in the nasal polyps from patients with AERD. In a randomized, double-blind, placebo-controlled study of mepolizumab for nasal polyposis, 12 of 20 patients in the treatment group had a significant reduction in nasal polyp size as measured by improved nasal polyp score and computed tomography scans 1 month after dosing. Five of the 20 patients in the treatment group had aspirin sensitivity by history. ${ }^{52}$ A multicenter, randomized, double-blind, placebocontrolled investigation of mepolizumab reducing need for surgery in nasal polyps was recently completed (NCT01362244).

Dupilumab, a fully humanized monoclonal antibody, which binds the alpha subunit of the IL-4 receptor and modulates signaling of the Th2 cytokines IL-4 and IL-13, has been investigated in several atopic diseases, including eosinophilic asthma and atopic dermatitis. ${ }^{53,54}$ A recently completed phase II study of dupilumab in bilateral nasal polyps included 60 patients and assessed the endoscopic nasal polyp score in comparison to placebo (NCT01920893). The formal results of this same study are currently pending, but a preliminary press release from the sponsor reported that treatment with dupilumab resulted in statistically significant reductions in nasal polyp size, along with improvements in patient-reported symptoms of sense of smell 
and nasal congestion. Dupilumab has not yet been studied specifically in AERD.

\section{Dietary interventions}

Dietary interventions targeting the dysregulated arachidonic acid pathway are also of interest in AERD. Given the known contribution of acetylsalicylic acid (aspirin) to the pathognomonic respiratory reactions in AERD and several previously published case reports of salicylate reactions in AERD patients, ${ }^{55,56}$ a low salicylic acid diet was explored as a therapeutic intervention. Sommer et al. ${ }^{57}$ conducted a prospective crossover study examining a low salicylate diet in 10 patients with AERD. Dietary sources of salicylates, including many fruits, vegetables, herbs, spices, almonds, and several oils, were eliminated from subjects' diets for 6 weeks. Of the 10 subjects who were able to complete the study, both subjective symptom scores and blinded physician endoscopic evaluation improved while on the low salicylate diet as compared to a regular diet. ${ }^{57}$ A limitation of the study is that it was not blinded to subjects, and the outcomes measured were primarily subjective symptom scores.

An ongoing dietary trial is evaluating the effect of a high omega-3, low omega-6 fatty acid diet in AERD (NCT02064738). This approach targets the proinflammatory lipids formed from the metabolism of omega- 6 fatty acids, which play a role in the formation of inflammatory lipid mediators important in the pathobiology of AERD, including $\mathrm{PGD}_{2}, \mathrm{TXA}_{2}$, and $\mathrm{LTB}_{4}, \mathrm{LTC}_{4}$, $\mathrm{LTD}_{4}$, and LTE 4 . Reducing omega- 6 fatty acids in the diet may decrease the production of these inflammatory mediators derived from arachidonic acid, whereas increased dietary omega-3 fatty acids may lead to increased metabolic products of eicosapentaenoic acid, which exert less inflammatory biologic activity. ${ }^{58}$ Mechanistic outcomes (decrease in urinary and serum leukotrienes) and subjective symptom scoring will be assessed.

\section{CONCLUSION}

The medical management of AERD is multifaceted and targets a variety of the inflammatory mediators and effector cells known to be important in the disease pathogenesis. Standard therapy includes guideline-based treatment of asthma and sinus disease with the addition of medications targeting the leukotriene pathway and avoidance of all COX-1 inhibitors. Most patients with AERD will benefit from aspirin desensitization and initiation of high-dose daily aspirin therapy. Therapies targeting platelets in AERD are currently under investigation. Additionally, therapeutics specifically targeting inflammatory lipid mediators and Th2 cytokines may also prove beneficial. Therefore, many therapies in development hold promise for the treatment of AERD in the future.

\section{ORCID}

Kathleen M. Buchheit http://orcid.org/0000-0001-5977-851X

\section{REFERENCES}

1. Rajan JP, Wineinger NE, Stevenson DD, White AA. Prevalence of aspirin-exacerbated respiratory disease among asthmatic patients: a meta-analysis of the literature. J Allergy Clin Immunol 2015;135: 676-81.e1.

2. SzczeklikA, Nizankowska E, Duplaga M. Natural history of aspirininduced asthma. AIANE Investigators. European Network on Aspirin-Induced Asthma. Eur Respir J 2000;16:432-6.

3. Berges-Gimeno MP, Simon RA, Stevenson DD. The natural history and clinical characteristics of aspirin-exacerbated respiratory disease. Ann Allergy Asthma Immunol 2002;89:474-8.

4. Cahill KN, Bensko JC, Boyce JA, Laidlaw TM. Prostaglandin D(2): a dominant mediator of aspirin-exacerbated respiratory disease. J Allergy Clin Immunol 2015;135:245-52.

5. Kowalski ML, Makowska JS. Seven steps to the diagnosis of NSAIDs hypersensitivity: how to apply a new classification in real practice? Allergy Asthma Immunol Res 2015;7:312-20.

6. Cahill KN, Laidlaw TM. Aspirin exacerbated respiratory disease: the search for a biomarker. Ann Allergy Asthma Immunol 2014; 113:500-1.

7. Christie PE, Tagari P, Ford-Hutchinson AW, Charlesson S, Chee P, Arm JP, et al. Urinary leukotriene E4 concentrations increase after aspirin challenge in aspirin-sensitive asthmatic subjects. Am Rev Respir Dis 1991;143:1025-9.

8. Kanaoka Y, Boyce JA. Cysteinyl leukotrienes and their receptors; emerging concepts. Allergy Asthma Immunol Res 2014;6:288-95.

9. Sladek K, Dworski R, Soja J, Sheller JR, Nizankowska E, Oates JA, et al. Eicosanoids in bronchoalveolar lavage fluid of aspirin-intolerant patients with asthma after aspirin challenge. Am J Respir Crit Care Med 1994;149:940-6.

10. Bochenek G, Nagraba K, Nizankowska E, Szczeklik A. A controlled study of 9alpha,11beta-PGF2 (a prostaglandin D2 metabolite) in plasma and urine of patients with bronchial asthma and healthy controls after aspirin challenge. J Allergy Clin Immunol 2003;111: 743-9.

11. Yoshimura T, Yoshikawa M, Otori N, Haruna S, Moriyama H. Correlation between the prostaglandin $\mathrm{D}(2) / \mathrm{E}(2)$ ratio in nasal polyps and the recalcitrant pathophysiology of chronic rhinosinusitis associated with bronchial asthma. Allergol Int 2008;57:429-36.

12. Cowburn AS, Sladek K, Soja J, Adamek L, Nizankowska E, Szczeklik A, et al. Overexpression of leukotriene $\mathrm{C} 4$ synthase in bronchial biopsies from patients with aspirin-intolerant asthma. J Clin Invest 1998;101:834-46.

13. Payne SC, Early SB, Huyett P, Han JK, Borish L, Steinke JW. Evidence for distinct histologic profile of nasal polyps with and without eosinophilia. Laryngoscope 2011;121:2262-7.

14. Laidlaw TM, Kidder MS, Bhattacharyya N, Xing W, Shen S, Milne GL, et al. Cysteinyl leukotriene overproduction in aspirin-exacerbated respiratory disease is driven by platelet-adherent leukocytes. Blood 2012;119:3790-8.

15. Sestini P, Armetti L, Gambaro G, Pieroni MG, Refini RM, Sala A, et al. Inhaled PGE2 prevents aspirin-induced bronchoconstriction and urinary LTE4 excretion in aspirin-sensitive asthma. Am J 
Respir Crit Care Med 1996;153:572-5.

16. National Asthma Education and Prevention Program. Expert Panel Report 3 (EPR-3): guidelines for the diagnosis and management of asthma-summary report 2007. J Allergy Clin Immunol 2007;120: S94-138.

17. Peters AT, Spector S, Hsu J, Hamilos DL, Baroody FM, Chandra RK, et al. Diagnosis and management of rhinosinusitis: a practice parameter update. Ann Allergy Asthma Immunol 2014;113:347-85.

18. Macy E, Bernstein JA, Castells MC, Gawchik SM, Lee TH, Settipane RA, et al. Aspirin challenge and desensitization for aspirin-exacerbated respiratory disease: a practice paper. Ann Allergy Asthma Immunol 2007;98:172-4.

19. Gollapudi RR, Teirstein PS, Stevenson DD, Simon RA. Aspirin sensitivity: implications for patients with coronary artery disease. JAMA 2004;292:3017-23.

20. Woessner KM, Simon RA. Cardiovascular prophylaxis and aspirin "allergy". Immunol Allergy Clin North Am 2013;33:263-74.

21. Kim YJ, Lim KH, Kim MY, Jo EJ, Lee SY, Lee SE, et al. Cross-reactivity to acetaminophen and celecoxib according to the type of nonsteroidal anti-inflammatory drug hypersensitivity. Allergy Asthma Immunol Res 2014;6:156-62.

22. Stevenson DD, Pleskow WW, Simon RA, Mathison DA, Lumry WR, Schatz M, et al. Aspirin-sensitive rhinosinusitis asthma: a doubleblind crossover study of treatment with aspirin. J Allergy Clin Immunol 1984;73:500-7.

23. McMains KC, Kountakis SE. Medical and surgical considerations in patients with Samter's triad. Am J Rhinol 2006;20:573-6.

24. Berges-Gimeno MP, Simon RA, Stevenson DD. Long-term treatment with aspirin desensitization in asthmatic patients with aspirin-exacerbated respiratory disease. J Allergy Clin Immunol 2003; 111:180-6.

25. Berges-Gimeno MP, Simon RA, Stevenson DD. Early effects of aspirin desensitization treatment in asthmatic patients with aspirinexacerbated respiratory disease. Ann Allergy Asthma Immunol 2003;90:338-41.

26. Stevenson DD, Hankammer MA, Mathison DA, Christiansen SC, Simon RA. Aspirin desensitization treatment of aspirin-sensitive patients with rhinosinusitis-asthma: long-term outcomes. J Allergy Clin Immunol 1996;98:751-8.

27. Świerczyńska-Krępa M, Sanak M, Bochenek G, Stręk P, Ćmiel A, Gielicz A, et al. Aspirin desensitization in patients with aspirin-induced and aspirin-tolerant asthma: a double-blind study. J Allergy Clin Immunol 2014;134:883-90.

28. Rozsasi A, Polzehl D, Deutschle T, Smith E, Wiesmiller K, Riechelmann $\mathrm{H}$, et al. Long-term treatment with aspirin desensitization: a prospective clinical trial comparing 100 and $300 \mathrm{mg}$ aspirin daily. Allergy 2008;63:1228-34.

29. Shaker M, Lobb A, Jenkins P, O'Rourke D, Takemoto SK, Sheth S, et al. An economic analysis of aspirin desensitization in aspirin-exacerbated respiratory disease. J Allergy Clin Immunol 2008;121:81-7.

30. Lee JY, Simon RA, Stevenson DD. Selection of aspirin dosages for aspirin desensitization treatment in patients with aspirin-exacerbated respiratory disease. J Allergy Clin Immunol 2007;119:157-64.

31. Dahlén SE, Malmström K, Nizankowska E, Dahlén B, Kuna P, Kowalski M, et al. Improvement of aspirin-intolerant asthma by montelukast, a leukotriene antagonist: a randomized, double-blind, placebo-controlled trial. Am J Respir Crit Care Med 2002;165:9-14.

32. Lee DK, Haggart K, Robb FM, Lipworth BJ. Montelukast protects against nasal lysine-aspirin challenge in patients with aspirin-in- duced asthma. Eur Respir J 2004;24:226-30.

33. Kieff DA, Busaba NY. Efficacy of montelukast in the treatment of nasal polyposis. Ann Otol Rhinol Laryngol 2005;114:941-5.

34. Ta V, White AA. Survey-defined patient experiences with aspirin-exacerbated respiratory disease. J Allergy Clin Immunol Pract 2015; 3:711-8.

35. Watkins PB, Dube LM, Walton-Bowen K, Cameron CM, Kasten LE. Clinical pattern of zileuton-associated liver injury: results of a 12-month study in patients with chronic asthma. Drug Saf 2007; 30:805-15.

36. Wenzel S, Busse W, Calhoun W, Panettieri R Jr, Peters-Golden M, Dube L, et al. The safety and efficacy of zileuton controlled-release tablets as adjunctive therapy to usual care in the treatment of moderate persistent asthma: a 6-month randomized controlled study. J Asthma 2007;44:305-10.

37. Bobolea I, Barranco P, Fiandor A, Cabañas R, Quirce S. Omalizumab: a potential new therapeutic approach for aspirin-exacerbated respiratory disease. J Investig Allergol Clin Immunol 2010;20:448-9.

38. Bergmann KC, Zuberbier T, Church MK. Omalizumab in the treatment of aspirin-exacerbated respiratory disease. J Allergy Clin Immunol Pract 2015;3:459-60.

39. Gevaert P, Calus L, Van Zele T, Blomme K, De Ruyck N, Bauters W, et al. Omalizumab is effective in allergic and nonallergic patients with nasal polyps and asthma. J Allergy Clin Immunol 2013;131:1106.el.

40. Johns CB, Laidlaw TM. Elevated total serum IgE in nonatopic patients with aspirin-exacerbated respiratory disease. Am J Rhinol Allergy 2014;28:287-9.

41. Klinkhardt U, Bauersachs R, Adams J, Graff J, Lindhoff-Last E, Harder S. Clopidogrel but not aspirin reduces P-selectin expression and formation of platelet-leukocyte aggregates in patients with atherosclerotic vascular disease. Clin Pharmacol Ther 2003;73:232-41.

42. Paruchuri S, Tashimo H, Feng C, Maekawa A, Xing W, Jiang Y, et al. Leukotriene E4-induced pulmonary inflammation is mediated by the P2Y12 receptor. J Exp Med 2009;206:2543-55.

43. Cummings HE, Liu T, Feng C, Laidlaw TM, Conley PB, Kanaoka Y, et al. Cutting edge: Leukotriene C4 activates mouse platelets in plasma exclusively through the type 2 cysteinyl leukotriene receptor. J Immunol 2013;191:5807-10.

44. Liu T, Laidlaw TM, Katz HR, Boyce JA. Prostaglandin E2 deficiency causes a phenotype of aspirin sensitivity that depends on platelets and cysteinyl leukotrienes. Proc Natl Acad Sci U S A 2013;110: 16987-92.

45. Kim SH, Choi JH, Park HS, Holloway JW, Lee SK, Park CS, et al. Association of thromboxane A2 receptor gene polymorphism with the phenotype of acetyl salicylic acid-intolerant asthma. Clin Exp Allergy 2005;35:585-90.

46. Flood-Page P, Swenson C, Faiferman I, Matthews J, Williams M, Brannick L, et al. A study to evaluate safety and efficacy of mepolizumab in patients with moderate persistent asthma. Am J Respir Crit Care Med 2007;176:1062-71.

47. Bel EH, Wenzel SE, Thompson PJ, Prazma CM, Keene ON, Yancey SW, et al. Oral glucocorticoid-sparing effect of mepolizumab in eosinophilic asthma. N Engl J Med 2014;371:1189-97.

48. Nair P, Pizzichini MM, Kjarsgaard M, Inman MD, Efthimiadis A, Pizzichini E, et al. Mepolizumab for prednisone-dependent asthma with sputum eosinophilia. N Engl J Med 2009;360:985-93.

49. Haldar P, Brightling CE, Hargadon B, Gupta S, Monteiro W, Sousa A, et al. Mepolizumab and exacerbations of refractory eosinophilic 
asthma. N Engl J Med 2009;360:973-84

50. Ortega HG, Liu MC, Pavord ID, Brusselle GG, FitzGerald JM, Chetta A, et al. Mepolizumab treatment in patients with severe eosinophilic asthma. N Engl J Med 2014;371:1198-207.

51. Pavord ID, Korn S, Howarth P, Bleecker ER, Buhl R, Keene ON, et al. Mepolizumab for severe eosinophilic asthma (DREAM): a multicentre, double-blind, placebo-controlled trial. Lancet 2012;380: 651-9.

52. Gevaert P, Van Bruaene N, Cattaert T, Van Steen K, Van Zele T, Acke F, et al. Mepolizumab, a humanized anti-IL-5 mAb, as a treatment option for severe nasal polyposis. J Allergy Clin Immunol 2011; 128:989-95.e1-8.

53. Wenzel S, Ford L, Pearlman D, Spector S, Sher L, Skobieranda F, et al. Dupilumab in persistent asthma with elevated eosinophil levels. N Engl J Med 2013;368:2455-66.

54. Beck LA, Thaçi D, Hamilton JD, Graham NM, Bieber T, Rocklin R, et al. Dupilumab treatment in adults with moderate-to-severe atopic dermatitis. N Engl J Med 2014;371:130-9.

55. Chudwin DS, Strub M, Golden HE, Frey C, Richmond GW, Luskin AT. Sensitivity to non-acetylated salicylates in a patient with asthma, nasal polyps, and rheumatoid arthritis. Ann Allergy 1986;57: 133-4.

56. Park HS, Lim YS, Suh JE, Rhu NS, Cho DI, Kim JW. Sodium salicylate sensitivity in an asthmatic patient with aspirin sensitivity. J Korean Med Sci 1991;6:113-7.

57. Sommer DD, Hoffbauer S, Au M, Sowerby LJ, Gupta MK, Nayan S. Treatment of aspirin exacerbated respiratory disease with a low salicylate diet: a pilot crossover study. Otolaryngol Head Neck Surg 2015;152:42-7.

58. Healy E, Newell L, Howarth P, Friedmann PS. Control of salicylate intolerance with fish oils. Br J Dermatol 2008;159:1368-9. 